\title{
Inisiasi Pembentukan Usaha Baru Melalui Pemberdayaan untuk Mewujudkan Kemandirian Ekonomi Warga
}

\author{
Initiation for the Establishment of New Enterprises Through Empowerment to Create \\ Citizens Economic Independence
}

\author{
Muhammad Zakiy \\ Universitas Muhammadiyah Yogyakarta \\ email: zakiy_ishak@yahoo.com
}

DOI:

10.30595/jppm.v5i1.7159

Histori Artikel:

Diajukan:

09/04/2020

Diterima:

$21 / 03 / 2021$

Diterbitkan:

30/03/2021

\begin{abstract}
ABSTRAK
Program ini bertujuan untuk mengasah potensi masyarakat desa Trimurti, Srandakan Bantul yang dilakukan melalui pemberdayaan Kelompok Wanita Tani (KWT). Membangun motivasi masyarakat agar dapat menuju kemandirian pangan dan ekonomi masyarakat yang mandiri. Luaran yang dihasilkan adalah terbentuknya Kelompok Wanita Tani (KWT) di dusun Pedak, produk berupa tanaman buah dan sayur yang siap dikonsumsi dan dijual ke pasar-pasar terdekat. Selain itu, kegiatan ini juga menghidupkan kembali program kemandirian desa yang dicanangkan kabupaten Bantul dan membantu masyarakat untuk mengisi kekosongan yang dapat menghasilkan penghasilan tambahan. Sebagai sasaran pengabdian ini adalah kelompok masyarakat dusun Pedak yang tergabung memiliki ketertarikan dalam tanaman pekarangan sempit. Pemilihan mitra ini dikarenakan potensi dari pekarangan rumah di dusun Pedak dapat ditanami tanaman buah dan sayur serta minat masyarakat khususnya IRT dalam budidaya tanaman. Kegiatan ini dilakukan dengan memberikan motivasi bagi IRT untuk mencoba kegiatan baru yang menarik dan dapat menghasilkan penghasilan tambahan melalui metode diskusi dan pelatihan praktis penanaman dan budidaya oleh instruktur yang ahli dalam bidang pertanian, serta menginisiasi terbentuknya Kelompok Wanita Tani (KWT). Adapun langkah-langkah yang ditempuh meliputi tahap persiapan dan tahap pelaksanaan melalui observasi, penyiapan materi pelatihan, mengagendakan waktu pelatihan, pemberian motivasi, pelatihan dan pendampingan, monitoring dan laporan akhir.
\end{abstract}

Kata kunci: Dusun Pedak; KWT; Tanaman Rumah; KKN UMY

\begin{abstract}
This program aims to hone the Trimurti village community's potential, Srandakan Bantul, which is carried out through the Kelompok Wanita Tani (KWT) empowerment. Building community motivation so that it can lead to food independence and community economy independence. The resulting output is the formation of the Kelompok Wanita Tani $(K W T)$ in the village of Pedak, the products are in the form of fruit and vegetable plants that are ready to be consumed and sold to the nearest markets. Besides, this activity also revived the village independence program launched by Bantul district and helped the community to fill in the gaps that could generate additional income. As the target of this service, the Pedak incorporated community group interested in narrow yard plants. The choice of the colleague is due to the potential of the home yard in the village of Pedak to be planted with fruit and vegetable as well as community interest, especially IRT in plant cultivation. This activity is done by providing motivation for IRT to try new activities that are interesting and generate additional income through discussion methods and practical training on cultivation by instructors who are experts in the field of agriculture and initiate the formation of the Kelompok Wanita Tani (KWT). The steps taken include the preparation and implementation stages through observation, preparation of training materials, scheduling training time, motivating, training and mentoring, monitoring and final report.
\end{abstract}




\section{PENDAHULUAN}

Desa Trimurti berjarak kurang lebih $10 \mathrm{~km}$ dari pusat kota Bantul dan $20 \mathrm{~km}$ dari Universitas Muhammadiyah Yogyakarta. Desa ini tergabung dalam Kecamatan Srandakan, Kabupaten Bantul, Daerah Istimewa Yogyakarta. Daerah dengan kondisi dataran rendah ini banyak dilalui kendaraan lintas kota maupun lintas propinsi yang menjadikan daerah Trimurti memiliki keuanggulan tersendiri dalam hal pengembangan ekonomi warga untuk berwirausaha. Letak desa yang strategis karena menghubungkan kabupaten Bantul dan Kulonprogo menjadikan desa ini memiliki potensi untuk berkembang yang sangat baik. Selain itu posisi desa yang dekat dengan arah bandara baru Kulonprogo dan tempat wisata pantai di Bantul menjadikan desa ini berpotensi untuk pemasaran sebuah bisnis. Seperti yang dikutip Noermawati et al. (2018) yang menjelaskan bahwa dekatnya lokasi bisnis dengan pusat bisnis menjadikan sebuah usaha memiliki economic rent yang tinggi. Didukung dengan budaya gotong royong yang kental, menjadikan desa ini dapat dijadikan Kelompok Usaha Bersama (KUB). Adapun mayoritas pekerjaan masyarakat di desa ini adalah sebagai karyawan, buruh, dan pedagang warung yang terlihat kurang berkembang. Untuk itu diperlukan pemberdayaan agar dapat meningkatkan pendapatan dan memperbaiki keadaan ekonomi masyarakat sekitar.

Setelah melakukan pengamatan awal terhadap kondisi lingkungan dan diskusi dengan pengurus desa serta masyarakat desa Trimurti, tim Pengabdian menemukan beberapa potensi yang dapat dikembangkan dari desa ini. Potensi pertama yang coba dikembangkan yaitu membangun motivasi masyarakat dalam memulai bisnis melalui sosialisasi dan pelatihan kewirausahaan bagi masyarakat yang belum bekerja atau pekerjaannya tidak tetap agar dapat diberdayakan. Hal ini seperti yang dijelaskan oleh Widjajanti (2011) tentang konsep pemberdayaan yaitu suatu proses dan upaya untuk memperoleh atau memberikan daya, kekuatan atau kemampuan kepada individu dan masyarakat lemah agar dapat mengidentifikasi, menganalisis, menetapkan kebutuhan dan potensi serta masalah yang dihadapi dan sekaligus memilih alternatif pemecahannya dengan mengoptimalkan sumber daya dan potensi yang dimiliki secara mandiri.

Program kedua yang dapat dilaksanakan di desa Trimurti ini yaitu dengan pemanfaatan lahan pekarangan rumah untuk bertani tumbuh-tumbuhan yang dapat dijual di pasar. Program ini dikembangkan karena di desa Trimurti tidak terdapat ladang sawah untuk padi sehingga masyarakat dapat memanfaatkan lahan pekarangan rumahnya untuk diadikan lahan bisnis. Tanaman yang akan ditanam berupa tanaman kecil seperti sayuran, dan buah-buahan. Selain itu, program ini dilakukan karena program ini sejalan dengan program pemerintah kabupaten Bantul yang menggalakkan kelompok tani seperti Kelompok Wanita Tani (KWT). Program seperti ini telah banyak dilakukan di masyarakat-masyarakat perkotaan yang memiliki lahan pekarangan yang dapat dimanfaatkan. Pemanfaatan pekarangan juga telah dibuktikan dapat mendukung ketahanan pangan dan memperindah halam rumah (Dwiratna et al., 2016; Rauf et al., 2014; Purwantini, 2016).

Pemanfaatan lahan pekarangan ini, selain memperindah dan menambah asri halaman rumah, juga dapat dijadikan sumber pendapatan. Masyarakat dapat mencoba membuat kelompok tani desa yang hasil pertaniannya dapat dimanfaatkan secara pribadi maupun dikumpulkan kemudian dijual. Dari kelompok tani ini bisa dibentuk Kelompok Usaha Bersama (KUB) dimana lebih menguntungkan bagi masyarakat. Selain itu dengan KUB juga dapat menjadi alternative pendirian koperasi yang harapannya dapat meningkatkan modal usaha bagi KUB itu sendiri dan masyarakat sekitar.

Letak geografis desa Trimurti yang sangat mendukung dalam berwirausaha, menjadikan KUB Masyarakat harus dibuat. 
Dari KUB ini nantinya dapat dijadikan percontohan bagi desa-desa yang lain dalam hal pemanfaatan lahan pekarangan sempit untuk dijadikan peluang usaha. Selain itu pemanfaatan lahan sempit ini juga dapat dijadikan tempat wisata urban farming bagi masyarakat yang akan berkunjung ke tempat wisata pantai di daerah Bantul. Dari hasil pengembangan motivasi dan pelatihan pembuatan pertanian pekarangan sempit ini, diharapkan dapat meningkatkan partisipasi masyarakat dalam pembentukan KUB sehingga dapat meningkatkan perekonomian masyarakat desa Trimurti.

\section{METODE}

Pemberdayaan masyarakat desa Trimurti dibagi menjadi 3 tahap Garapan yaitu motivasi peningkatan kewirausahaan, praktek wirausaha, dan pengembangan usaha. Dalam tahap motivasi, tim pengabdian mengumpulkan warga yang akan menjadi sasaran untuk dilakukan pemberdayaan. Tahap kedua, menentukan jenis usaha berupa pertanian lahan sempit dan mempraktekkan/ mendemonstrasikan. Pada tahap terakhir, tim pengabdian mempromosikan/ mencari alaternatif-alternatif pengembangan usaha. Keseluruhan proses ini dapat dijelaskan dalam gambar 1. Terdapat beberapa tahapan yang harus dilakukan tim pengabdian dalam mempersiapkan proses pemberdayaan ini antara lain:

\section{Tahap Persiapan dan Pembekalan}

a. Observasi

Observasi dilakukan guna mengetahui permasalahan yang dihadapi masyarakat, kemudian tim pengabdian membuat programprogram solusi yang dapat diterapkan. Kegiatan observasi ini dilakukan oleh dosen dan mahasiswa.

\section{b. Pembekalan kepada mahasiswa}

Pembekalan kepada mahasiswa bertujuan untuk menjelaskan peran mahasiswa dalam pelaksanaan program yang dikerjakan agar pembagian tugas dan tanggung jawab dapat berjalan dengan baik. Untuk itu dalam tahap ini, ketua tim pengabdian harus menjelaskan kepada mahasiswa secara rinci program yang dilaksanakan serta tahapan pelaksanaannya.

c. Perancangan program

Perancangan program dilakukan agar seluruh kegiatan yang dilakukan dapat berjalan dengan baik dan terstruktur. Perancangan meliputi pembuatan program, menghubungi pihak-pihak terkait serta penjadwalan kegiatan.

\section{Tahap Pelaksanaan}

a. Sosialisasi program yang akan dilaksanakan

Pada tahap ini tim pengabdian mengundang masyarakat/mitra untuk menjelaskan programprogram yang dilaksanakan selama 1 bulan ke depan dalam rangka pemberdayaan masyarakat agar lebih mandiri. Selain itu, tim juga manfaat-manfaat bagi masyarakat dari program yang dijalankan.

b. Pelatihan motivasi kewirausahaan (Achievement Motivation Training).

Pada tahap ini, tim pengabdian menjelaskan bahwa pentingnya berwirausaha untuk kemandirian ekonomi dan menghindari kemiskinan.

c. Pelatihan berwirausaha

Pada tahap ini, tim pengabdian melibatkan pelatih dan mahasiswa yang paham akan pertanian untuk melakukan pelatihan pemanfaatan lahan sempit untuk pertanian.

\section{d. Pelatihan mempromosikan produk}

Setelah produk yang dibuat selesai, maka tim pengabdian akan mencoba mencari saluran pemasaran produk seperti penjualan ke pasar, maupun penjualan langsung melalui online.

\section{e. Monitoring dan evaluasi}

Pada tahap ini tim pelaksana akan mengevaluasi program-program yang telah dilaksanakan bersama masyarakat. Selanjutnya dari hasil evaluasi ini direkomendasikan untuk pelaksanaan program yang akan dilaksanakan selanjutnya. 


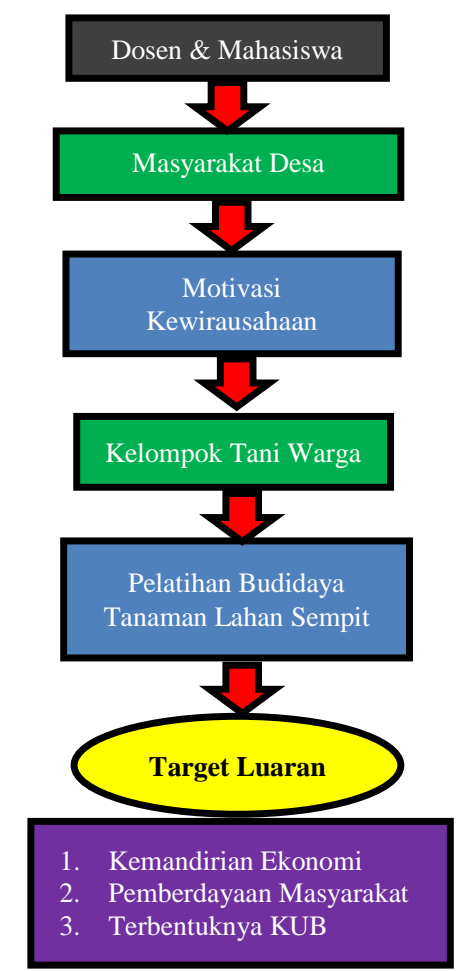

Gambar 1. Metode Pelaksanaan

HASIL DAN PEMBAHASAN

\section{Gambaran Umum dan Pelaksanaan Kegiatan}

Setelah ditentukan lokasi

pendampingan KKN UMY Gasal 2019/2020 oleh LP3M UMY, yaitu di Dusun Pedak, Desa Trimurti, Kecamatan Srandakan, Bantul, tim pengabdian yang terdiri dari Dosen dan Mahasiswa melakukan observasi awal lokasi KKN. Berdasarkan pengamatan awal yang dilakukan tim pengabdian, beberapa potensi yang dapat dikembangkan dan diberdayakan adalah pemanfaatan lahan rumah warga untuk ditanami tanaman jenis buah dan sayur. Mengingat tidak adanya lahan pertanian berupa sawah di desa tersebut, dan berdasarkan hasil diskusi dengan masyarakat, maka tim pengabdian memutuskan untuk fokus mengembangkan pertanian lahan sempit. Keputusan ini dibuat karena mayoritas pekerjaan kaum wanita di dusun ini adalah Ibu Rumah Tangga (IRT) yang banyak memiliki waktu luang untuk menggarap tanaman buah dan sayur di halaman rumahnya.

Melihat letak geografis yang sangat strategis yaitu perbatasan dengan kabupaten
Kulonprogo, maka tim pengabdian melihat potensi pengembangan usaha di daerah ini sangat prospek ke depannya. Selain dekat dengan jalan alternatif menuju bandara baru Yogyakarta, daerah ini juga dekat dengan tempat wisata pantai Kabupaten Bantul yaitu pantai Goa Cemara, Pantai Baru, dan Pantai Glagah di Kulonprogo. Hal ini menjadikan daerah ini bisa menjadi alternatif pemasok bahan baku buah dan sayur di daerah wisata tersebut. Program yang tidak sulit dan masyarakat dapat selalu memantau perkembangan usahanya menjadikan pengembangan tanaman pekarangan sempit menjadi sebuah kegiatan yang perlu untuk dicoba untuk menuju kemandirian ekonomi dan pangan masyarakat dusun Pedak.

\section{Persiapan Pelaksanaan Pengabdian}

Sebelum melakukan kegiatan pemberdayaan, tim pengabdian melakukan observasi lokasi dan diskusi dengan beberapa tokoh masyarakat dan perangkat desa untuk mengidentifikasi permasalahan mitra. Setelah mengetahui permasalahan dan kebutuhan yang diperlukan, maka tim membuat rencana program pemberdayaan yang sesuai dengan kebutuhan mitra. Setelah memilih beberapa kegiatan yang akan dilakukan, tim pengabdian mempersiapkan kebutuhan dan metode pemberdayaan yang sesuai sasaran dilanjutkan dengan penjadwalan program pelatihan antara tim pengabdian, pelatih dan mitra pengabdian sehingga program yang dilakukan dapat sesuai dengan tujuan yang diinginkan dan masyarakat mitra dapat diberdayakan dengan baik. Selain itu, tahap persiapan ini merupakan langkah awal dan sangat penting bagi setiap program yang akan dilaksanakan.

Program yang dilaksanakan didahului dengan sosialisasi kepada masyarakat mitra mengenai program yang dilaksanakan serta penjelasan mengenai manfaat-manfaat yang didapat oleh masyarakat terkait program yang dilaksanakan. Dalam kesempatan ini juga, tim pengabdian membangun motivasi dan komitmen masyarakat mitra agar dapat berpartisipasi penuh dalam program yang dilaksanakan. Diskusi dan sosialisasi ini membahas mengenai teknis pelaksanaan pelatihan, persiapan tempat/lahan, peralatan dan perlengkapan yang dibutuhkan, serta 
pembagian tugas dari setiap anggota masyarakat mitra. Dalam penyampaian sosialisasi dan membangun motivasi dan komitmen masyarakat, diberikan materi mengenai pemberdayaan dan keterlibatan masyarakat agar senantiasa memberikan kontribusi dalam program yang dilakukan agar masyarakat dapat menuju kemandirian pangan dan kemandirian ekonomi. Selain itu masyarakat juga dijelaskan mengenai Koperasi melalui Kelompok Usaha Bersama (KUB) yang harapannya dapat dibentuk di akhir program ini. Selain pemberian motivasi dan membangun komitmen anggota mitra, tim pengabdian juga memberikan materi mengenai entrepreneur meliputi rencana bisnis, produksi, distribusi serta pemasaran.

\section{Pembuatan Materi dan Bahan}

Dalam tahapan ini, tim pengabdian berkoordinasi dengan masyarakat mitra untuk membentuk dan menentukan jenis pelatihan yang dibutuhkan dari beberapa alternatif pilihan yang ada. Setelah memilih jenis pelatihan, maka tim menyediakan materi dan bahan yang dibutuhkan berupa tempat/lahan pertanian, instruktur, bibit tanaman, peralatan dan bahan habis pakai. Untuk lahan pertanian dan pelatih sudah disediakan warga bekerjasama dengan salah satu anggota mitra dan aparatur desa. Adapun peralatan dan bahan yang lain seperti polybag, pupuk, bibit tanaman, dan alat angkut disediakan tim pengabdian. Selain itu, tim pengabdian juga memfasilitasi bahan konsumsi yang dimasak oleh anggota mitra untuk dikonsumsi bersama.

\section{Praktek Pelaksanaan Kegiatan Pengabdian}

Pelaksanaan pelatihan Kelompok

Wanita Tani (KWT) ini dilakukan setelah disepakati waktu dan tempat oleh tim pengabdian, masyarakat mitra, dan pelatih. Pelatihan pertama dilaksanakan pada sabtu 25 Januari 2020 pukul 08.00 sd 11.30. dengan agenda mempersiapkan lahan untuk ditanami dengan kegiatan membersihkan lahan pekarangan, membuat patok dan membuat media tanam. Dalam pelatihan awal ini hampir seluruh masyarakat mitra terlibat aktif dengan dibantu oleh tim pengabdian yang terdiri dari dosen dan mahasiswa. Kegiatan berjalan lancar dengan output tersedianya lahan untuk siap ditanami bibit buah dan sayur, pagar pelindung dari hama, dan pengumpulan peralatan dan perlengkapan disatu tempat yaitu gudang KWT. Selain itu, output dari pelatihan pertama ini masyarakat memiliki keterampilan dalam mempersiapkan lahan dan media tanam untuk lahan sempit yang bisa dipraktekkan di rumah masing-masing.

Pelatihan kedua dilakukan pada hari Sabtu tanggal 1 Februari 2020 pukul 8.00 sd 11.00 dengan agenda mananam bibit tanaman sayur dan buah. Lahan yang sudah dipersiapkan seminggu sebelumnya sudah siap ditanami warga dengan beberapa jenis tanaman buah dan sayur seperti terong, cabai, tomat, dan melon. Kegiatan ini diikuti oleh mayoritas anggota KWT dan kegiatan yang dilakukan selain menanam, juga mempersiapkan pupuk dan penyiraman tanaman agar dapat tumbuh subur. Setelah proses bercocok tanam dilakukan, anggota KWT juga secara bergantian mengelola dan mengawasi tanaman yang sudah mulai tumbuh sambil menyiram dan memberi pupuk. Setelah 2 pekan berjalan, tim Pengabdian meninjau lokasi pertanian yang dikelola KWT dan melihat secara langsung hasil dari program yang dilaksanakan untuk pemberdayaan masyarakat. Dari program ini, pihak mitra sangat antusias untuk mengembangkan pertanian di lahan sempit yang terlihat sangat sederhana, namun banyak memberikan manfaat bagi masing-masing rumah tangga.

Setelah meninjau hasil dari program yang telah dilakukan, dan melihat perkembangan yang sangat baik dan antusias masyarakat dalam menyambut program ini sangat positif, maka tim pengabdian berusaha untuk mencari lokasi penjualan produk agar produk yang dihasilkan dapat dipasarkan kepada masyarakat secara luas. Tim pengabdian mengunjugi beberapa tempat seperti pasar tradisional, tempat wisata maupun penjual sayur yang menyediakan sayuran untuk dijual. Selain itu tim pengabdian juga memberikan materi pemasaran produk agar produk yang dihasilkan dapat dipasarkan melalui media sosial dan situs jual beli online. Materi pemasaran yang diberikan dapat berbentuk foto, video maupun WoM dari masyarakat sekitar. 
Dari keseluruhan program yang dilakukan tim pengabdian ini, dapat dikatakan telah memenuhi tujuan diselenggarakannya program pemberdayaan ini. Hal ini dapat dilihat dari antusias dan motivasi masyarakat untuk mengikuti kegiatan ini sangat tinggi, karena kegiatan yang dilakukan relative mudah dan dapat dipraktekkan sendiri di rumah masing-masing yang memanfaatkan lahan pekarangan sempit yang ada di rumahnya. Masyarakat juga memiliki pengetahuan dan keterampilan dalam bercocok tanam untuk mengisi waktu luang sehari-hari. Respon dari masyarakat terhadap program pemberdayaan ini juga sangat baik dan semuanya merasa mendapatkan manfaat dari diadakannya program ini. Selain itu, dengan adanya program ini, masyarakat Dusun Pedak sudah memiliki kelompok/kegiatan yang bisa dilakukan Bersama yaitu Kelompok Wanita Tani (KWT).

\section{SIMPULAN}

Program yang dilaksanakan ini telah menghasilkan pemahaman bagi masyarakat akan pentingnya menggali potensi yang dimiliki untuk menghasilkan produk yang dapat menjadikan nilai tambah secara ekonomis. Program ini dapat berjalan dengan baik jika seluruh anggota KWT dapat berpartisipasi secara aktif dalam seluruh kegiatan yang dilaksanakan. Program ini juga telah memberikan nilai tambah untuk masyarakat sasaran dengan menjadikan masyarakat lebih terberdayakan secara ekonomi, sosial dan budaya.

\section{DAFTAR PUSTAKA}

Dwiratna, S., Widyasanti, A., \& Rahmah, D. M. (2016). Pemanfaatan Lahan Pekarangan Dengan Menerapkan Konsep Kawasan Rumah Pangan Lestari. Dharmakarya, 5(1), 19 - 22.

Noermawati, J., Pratiwi, A., Rozikan., \& Zakiy, M. (2019). Pemberdayaan kelompok hadroh dalam peningkatan status sosial dan ekonomi masyarakat di indonesia. In Seminar Nasional Hasil Penelitian \&
Pengabdian Kepada Masyarakat (SNP2M) (pp. 399-404).

Purwantini, T. B. (2016). Potensi dan prospek pemanfaatan lahan pekarangan untuk mendukung ketahanan pangan. In Forum Penelitian Agro Ekonomi, 30(1),13-30.

Rauf, A., Rahmawaty., \& Said, D.B. (2014). Sistem Pertanian terpadu di Lahan Pekarangan Mendukung Ketahanan Pangan Berkelanjutan dan Berwawasan Lingkungan. Jurnal Pertanian Tropik, 1(1), 1-8

Widjajanti, K. (2011). Model pemberdayaan masyarakat. Jurnal Ekonomi Pembangunan, 12(1), 15 - 27. 